\title{
A RESPONSABILIDADE CIVIL DOS FABRICANTES DE ALIMENTOS GENETICAMENTE MODIFICADOS: UMA ABORDAGEM AMBIENTAL E CONSUMERISTA
}

\author{
Elcio Nacur Rezende ${ }^{1}$ \\ Escola Superior Dom Helder Câmara (ESDHC)
}

Escola Superior Dom Helder Câmara (ESDHC)

Stela Gomes Ferreira ${ }^{3}$

Escola Superior Dom Helder Câmara (ESDHC)

Artigo recebido em: 16/09/2019.

Artigo aceito em: 01/10/2020.

\section{Resumo}

A produçáo de transgênicos tem crescido de maneira significativa. Todavia, as incertezas em torno dos efeitos para o consumo persistem, nesse sentido, a informação em seus rótulos deve ser clara e explicitar os riscos inerentes ao consumo, conforme disposição do Centers for Disease Control and Prevention (CDC). Contudo, o Projeto de Lei 4.148/2008 é divergente, dispensando essa obrigatoriedade. Portanto, este estudo tem como objetivo apurar a responsabilidade civil do fabricante de transgênicos quanto a ausência de informação no rótulo. Para tanto, utilizou-se a metodologia teórica-documental, com raciocínio dedutivo. Foi possível concluir que, apesar do caráter objetivo da responsabilidade, este poderá ser insuficiente para proteger o consumidor.

Palavras-chave: direito à informação; Direito Ambiental; Direito do Consumidor; organismos geneticamente modificados; responsabilidade civil.

1Pós-doutor, doutor e mestre em Direito. Professor da ESDHC. Procurador da Fazenda Nacional. ORCID: https:// orcid.org/0000-0002-2369-8945 / e-mail: elcionrezende@yahoo.com.br

2 Mestranda em Direito Ambiental e Desenvolvimento Sustentável pela ESDHC. ORCID: https://orcid.org/00000001-5129-7244 / e-mail: marinagasperini@hotmail.com

3 Mestranda em Direito Ambiental pela ESDHC ORCID: http://orcid.org/0000-0003-1610-8668 / e-mail: stelagferreira@gmail.com 


\section{THE CIVIL LIABILITY OF GENETICALLY MODIFIED FOOD SUPPLIERS: AN ENVIRONMENTAL AND CONSUMERIST APPROACH}

\section{Abstract}

The production of transgenics has grown significantly. However, the uncertainties surrounding the effects on consumption persist, in this sense, the information on their labels must be clear and explain the risks inherent in consumption, as provided by the Centers for Disease Control and Prevention (CDC). However, Law Project 4.148/2008 diverges, dispensing with this obligation. Therefore, this study aims to ascertain the civil liability of the transgenics supplier regarding the absence of information on the label. For this, the theoretical-documental methodology was used, with deductive reasoning. It was possible to conclude that despite the objective nature of the liability, it may be insufficient to protect the consumer.

Keywords: civil liability; Consumer Law; Environmental Law; genetic modified organism; right to information. 


\section{Introdução}

A biotecnologia tornou-se ferramenta largamente utilizada na produção de alimentos, por meio da engenharia genética, grande parte das sementes são transgênicas, derivadas dos Organismos Geneticamente Modificados (OGMs). Apesar de o consumo desses produtos estar inserido no cotidiano, existem, ainda, controvérsias científicas quanto a seus possíveis riscos e efeitos futuros. Desse modo, o estudo do tema justifica-se ante os possíveis reflexos tanto na seara consumerista, como ambiental.

O problema que se enfrentará consiste na responsabilidade do fabricante do alimento transgênico, derivado dos OGMs, haja vista a previsão legal da Lei de Biossegurança (11.105/2011). Portanto, é pertinente questionar se o instituto da responsabilidade civil permite a devida proteçâo do consumidor, visto sua vulnerabilidade na relação consumerista. Logo, levanta-se como premissa que, apesar de a responsabilidade ser objetiva, ainda é insuficiente para honrar ao princípio da devida informação.

Para tal, é necessária uma abordagem interdisciplinar que adentre diferentes ramos do Direito, como o Direito Ambiental e o do Consumidor, percorrendo também o instituto da responsabilidade civil.

Assim, o primeiro tópico visa definir tecnicamente o os OGMs e discorrer sobre sua introdução na agricultura brasileira; ademais, apresenta como sua temática deve ser tratada na égide de um Estado Ambiental de Direito. Já no segundo tópico a atenção se volta a discorrer sobre a relação consumerista com ênfase ao dever de informação imposto ao fabricante, ressaltando eventual mudança legislativa diante de projeto de lei em andamento. Por fim, analisa-se o instituto da responsabilidade civil para a construção do que concerne ao fabricante do alimento.

Utilizando a metodologia teórica-documental, com raciocínio dedutivo, vale-se da visão proposta por Maria Helena Diniz (2009) a qual sustenta que o Biodireito é capaz de trazer as respostas para as indagaçóes tecnológicas. Ademais, apoia-se nos apontamentos de Nelson Rosenvald (2017) acerca da responsabilidade civil, bem como de Tartuce (2018) para a compreensão da relação consumerista aqui analisada.

\section{Organismos geneticamente modificados}

Os organismos geneticamente modificados são fruto do avanço da biotecnologia moderna, a tecnologia que possibilitou seu desenvolvimento. O DNA recombinante (rDNA) teve início em 1972 pelo professor Paul Berg:

A tecnologia do DNA recombinante (rDNA) nasceu em 1972 quando o professor da Stanford University (USA) Paul Berg 
utilizou enzimas de restrição e uma DNA ligase para criar a primeira molécula de DNA recombinante. Ele produziu uma molécula híbrida e DNA com sequências de macaco, de um vírus que infecta símios (o SV40), e de outro vírus (lambda vírus) (ARAGÃO, 2020).

Nos anos 1980 foram geradas as primeiras plantas transgênicas, mas a partir de 1990, foram aprovadas as primeiras liberações comerciais para plantas transgênicas. "Em 1994, a primeira planta transgênica chegou ao mercado americano. Se tratava do tomate FLAVR-SAVR, modificado pela empresa Calgene para retardar o seu amadurecimento pós-colheita" (ARAGÃO, 2020). A partir dos anos 1990 houve um crescimento exponencial na criação de plantas transgênicas, a novidade foi o surgimento de plantas resistentes a insetos e herbicidas das maiores culturas mundiais como soja, milho e algodão, resultando em imensas áreas de cultivo de sementes transgênicas no Brasil e no Mundo.

No Brasil a aprovação comercial dos transgênicos ocorreu de maneira bastante controvertida. O debate acerca das consequências do consumo de OGMs teve início em 1996 e acirrou-se em 1998, quando a Monsanto ${ }^{4}$ requereu à Comissão Técnica Nacional de Biossegurança (CTNBio) a autorização para a comercialização no Brasil de sua soja transgênica. A partir desse momento, várias organizaçóes posicionaram-se contra a aprovação, o que resultou em uma Ação Civil Pública, cuja decisão proferida pelo Superior Tribunal de Justiça, proibiu a comercialização da semente no Brasil até que fossem realizados estudos que comprovassem sua inofensividade. Apesar da proibição baseada no princípio da precaução, o CTNBio, dias depois, proferiu parecer no sentido de que náo havia razão para a proibição e dispensou os estudos de impacto ambiental (PELAEZ, ALBERGONI, 2004, p. 208-209). A partir daí iniciou-se uma batalha judicial, cujo fim se deu em 2005 após a edição da Lei de Biossegurança, Lei 11.105/05, a qual solidificou o entendimento de que a CTNBio é órgão competente para dispor acerca da aprovação comercial de OGMs.

Várias medidas provisórias foram editadas entre o período de requerimento para a comercialização da soja transgênica e sua efetiva liberação, visto que, no sul do Brasil, principalmente no Rio Grande do Sul, os produtores rurais buscavam ilegalmente sementes transgênicas nos países vizinhos como Argentina e Paraguai, onde a comercializaçáo e o cultivo eram legais, para realizarem o plantio da safra. Então, o governo foi pressionado a editar uma série de medidas provisórias a fim de não impactar o mercado da soja no país por não poder comercializá-la. A Medida Provisória n. 113 de 2003, amplamente comentada à época, foi convertida em Lei pelo Senado Federal, Lei n. 10.688 de 2003 que dispóe "Art. 1º A comercialização da safra de soja de 2003 não estará sujeita às exigências pertinentes à Lei no 8.974, de 5 de janeiro de 1995, com as alteraçóes da Medida Provisória no 2.191-9, de 23 de agosto de 2001.” (BRASIL, 2003).

4 A Monsanto é a maior produtora de sementes transgênicas e herbicidas do mundo. 
Nesse sentido, é possível observar que a aprovação da comercialização de transgênicos no Brasil ocorreu em um cenário de muita pressão por parte dos produtores e da indústria, que ao criarem um mercado ilegal e realizarem grande parte do plantio da safra com sementes transgênicas, forçaram a edição de normas, e a liberação de sua comercialização sem os devidos estudos de impacto ambiental, uma vez que a não comercialização de parte da safra acarretaria prejuízos econômicos ao Estado.

Passada a liberação comercial dos transgênicos, estes foram difundidos cada vez mais no Brasil e ao redor do mundo, sendo responsáveis hoje por grande parte da produção de alimentos mundial. Em 2017, segundo o Serviço Internacional para Aquisição de Aplicaçôes de Agrobiotecnologia (ISAAA), 24 países plantaram 189.8 milhóes de hectares em sementes transgênicas, representando um aumento 112 vezes maior do que em 1996, quando foram plantados 1.7 milhóes de hectares (ISAAA, 2017, p. 2), já em 2018 "Vinte e seis países (21 em desenvolvimento e 5 países industrializados) plantaram 191, 7 milhóes de hectares de sementes transgênicas, o que adicionou 1, 9 milhóes de hectares ao recorde de plantios em

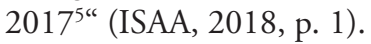

Internacionalmente, cabe destacar o Protocolo de Cartagena sobre Biossegurança, que faz parte da Convenção Sobre Diversidade Biológica, apesar de ter sido celebrado em 2000, o Brasil ratificou o protocolo apenas em 2003. Sendo regulamentado pelo Decreto n. 5.705 de 2006. O protocolo tem como objetivo:

Contribuir para assegurar um nível adequado de proteção no campo da transferência, da manipulação e do uso seguro dos organismos vivos modificados resultantes da biotecnologia moderna que possam ter efeitos adversos na conservação e no uso sustentável da diversidade biológica, levando em conta os riscos para a saúde humana, e enfocando especificamente os movimentos transfronteiriços (BRASIL, 2006).

No Brasil, no que tange aos organismos geneticamente modificados, a Lei de Biossegurança, veio para regulamentar os incs. II, IV e V do $₫ 1^{\circ}$ da Constituição Federal, bem como estabelecer normas de segurança e fiscalização em atividades que envolvam OGMs, além de criar o Conselho Nacional de Biossegurança (CNBS - BRASIL, 2005).

A Lei de Biossegurança dispóe acerca do papel da CTNBio no processo de liberação de organismos geneticamente modificados, quanto a elaboração de "normas técnicas de segurança e pareceres técnicos referentes à autorização para atividades que envolvam pesquisa e uso comercial de Organismos Geneticamente Modificados e seus derivados" (BRASIL, 2005). Além disso, o órgão é responsável

5 Twenty-six countries (21 developing and 5 industrialized countries) planted 191.7 million hectares of biotech crops, which added 1.9 million hectares to the record of plantings in 2017 (ISAAA, 2018, p. 1 - traduçáo livre do autor). 
por fazer uma classificaçáo de risco do OGM, a fim de se antecipar ou prevenir os possíveis riscos que a comercialização desse organismo trará para o meio ambiente, tendo competência para definir em última e definitiva instância acerca da necessidade de licenciamento ambiental.

Os conceitos determinantes para o entendimento do tema estáo dispostos nos incs. do art. $3^{\circ}$ da Lei 11.105/2005:

Art. 30 Para os efeitos desta Lei, considera-se: I - organismo: toda entidade biológica capaz de reproduzir ou transferir material genético, inclusive vírus e outras classes que venham a ser conhecidas; II - ácido desoxirribonucleico (ADN), ácido ribonucléico (ARN): Material genético que contém informaçōes determinantes dos caracteres hereditários transmissíveis à descendência; III moléculas de ADN/ARN recombinante: as moléculas manipuladas fora das células vivas mediante as modificaçóes de segmentos de ADN/ARN resultantes dessa multiplicação; IV - engenharia genética: atividade de produção e manipulaçấo de moléculas de ADN/ARN recombinante; $\mathrm{V}$ - organismo geneticamente modificado (OGM): organismo cujo material genético (ADN/ARN) tenha sido modificado por qualquer técnica de engenharia genética (BRASIL, 2005).

Nesse sentido, organismo geneticamente modificado é toda entidade biológica capaz de reproduzir ou transferir material genético, sendo considerado um OGM, qualquer material genético alterado por qualquer técnica de engenharia genética. A Lei de Biossegurança, nos parágrafos do art. 3 e no art. 4, também dispóe acerca das substâncias e técnicas que não se incluem na categoria de um organismo geneticamente modificado.

[...] $₫ 1^{\circ}$ Não se inclui na categoria de OGM o resultante de técnicas que impliquem a introdução direta, num organismo, de material hereditário, desde que não envolvam a utilização de moléculas de ADN/ARN recombinante ou OGM, inclusive fecundação in vitro, conjugaçâo, transdução, transformaçẫo, indução poliplóide e qualquer outro processo natural.

$\$ 2^{\circ}$ Não se inclui na categoria de derivado de OGM a substância pura, quimicamente definida, obtida por meio de processos biológicos e que não contenha $\mathrm{OGM}$, proteína heteróloga ou $\mathrm{ADN}$ recombinante.

Art. $4^{\circ}$ Esta Lei não se aplica quando a modificação genética for obtida por meio das seguintes técnicas, desde que não impliquem 
a utilização de OGM como receptor ou doador:

I - mutagênese;

II - formação e utilização de células somáticas de hibridoma ani$\mathrm{mal}$;

III - fusão celular, inclusive a de protoplasma, de células vegetais, que possa ser produzida mediante métodos tradicionais de cultivo;

IV - autoclonagem de organismos não-patogênicos que se processe de maneira natural (BRASIL, 2005).

O OGM caracteriza-se pela seleção da característica desejada no organismo doador, e a transferência dessa característica para o organismo desejado por meio de técnicas de edição genética, o que se diferencia do melhoramento genético convencional, uma vez que a edição genética permite a seleção precisa da característica desejada, enquanto que no melhoramento convencional, ainda que a característica desejada seja predominante, outras características também serão transmitidas no cruzamento entre os organismos. Nesse sentido:

Transgênicos são organismos que têm a estrutura genética alterada pela atividade da engenharia genética, que utiliza genes de outros organismos para dar àqueles novas características. Essa alteraçáo pode tanto buscar a melhora nutricional de um alimento como tornar a planta mais resistente a um herbicida (SILVA, 2001, p. 237).

Cabe ressaltar a diferença técnica conceitual entre OGM e transgênico, apesar de serem comumente tratados como sinônimos. Os OGMs são modificados a partir da inserçáo de material genético proveniente de um ser vivo da mesma espécie, já o transgênico é modificado a partir de material genético de uma espécie diferente da sua (ALVES, 2004, p. 4). Neste trabalho, para melhor compreensão, os conceitos serão utilizados como sinônimos a partir do conceito de OGM.

Apesar de sua popularidade na produção alimentícia mundial, os OGMs ainda são motivo de controvérsia, dada a ausência de estudos que comprovem sua inocuidade, atualmente, quase como à época de sua aprovação, permanecem cercados de incertezas quanto a seus efeitos para o consumo humano. Alguns dos possíveis efeitos são relatados por Maria Rafaela Junqueira Bruno Rodrigues:

No que tange ao meio ambiente, alerta-se sobre a possibilidade de afetar biotas estranhas àquela onde foi cultivado o alimento transgênico, por meio do deslocamento pelo vento, insetos, pólen. Outrossim, denota-se a hipótese de aparecer reaçóes adversas no organismo humano. Com efeito, pode ocorrer mutação celular, que resulte em menor resistência dos órgãos internos ou do 
sistema imunológico; os alimentos podem ser tóxicos, vez que sua modificaçấo pode causar o aparecimento de novas enzimas e toxinas; as reaçóes adversas, às vezes, podem aparecer após longo prazo de consumo contínuo, posto que algumas reações sejam acumulativas (RODRIGUES, 2003, p. 121-122).

As consequências relatadas são discutidas mundialmente, sendo um tema bastante controvertido, visto que os OGMs são apontados como causadores do surgimento de alergias alimentares, criadores dos chamados desertos verdes, ou áreas de grande cultivo de monocultura responsáveis pela extinção de quase toda a biodiversidade que ali habitava, etc. Outro ponto a ser ressaltado é a dependência do uso de determinados defensivos agrícolas nas plantas que são resistentes a um tipo específico de herbicida. Essa venda casada acabou monopolizando o mercado, fazendo que os produtores rurais majoritariamente sejam dependentes das empresas que disponibilizam essas tecnologias. Além disso, ao longo dos anos, alguns efeitos nocivos já foram constatados.

Sendo que o consumo de transgênicos denota riscos reais, os quais já foram comprovados por vários acidentes ocorridos. Este é o caso ocorrido nos Estados Unidos, em 1989, em que cinco mil pessoas adoeceram, trinta e sete mil morreram, e mais de mil e quinhentos ficaram com sequelas permanentes, após consumirem um complemento alimentar feito com bactérias geneticamente modificadas, denominadas de triptofano (aminoácido componente de proteínas), que ensejou a Síndrome de Eosinofilia-mialgia. Entenda-se por Eosinofilia aumento dos glóbulos brancos, e por mialgia, dores musculares. O suscitado complemento foi produzido pela empresa japonesa, Showa-Denko, que o retirou do mercado devido às consequências (RODRIGUES, 2003, p. 114-115).

Ainda que tenha havido uma grande evolução nas técnicas de edição genética e criação de organismos geneticamente modificados, não há como afirmar a inofensividade desses organismos, dada sua natureza e a imprevisibilidade inerente à edição genética.

Em contraponto à insegurança sobre seus resultados, os defensores de sua utilização acreditam que eles são responsáveis pela diminuição na utilização de agrotóxicos, uma vez que por serem resistentes a certos tipos de pragas e herbicidas, necessitariam de menores aplicaçôes de agrotóxicos. Além disso citam o aumento da produtividade, uma vez que são acometidos menos vezes por pragas, bem como o enriquecimento nutricional e maior retorno financeiro. 


\subsection{Organismos geneticamente modificados e o Estado Ambiental de Direito: a primazia do princípio da precauçáo}

Em 2050 a população mundial aumentará, provavelmente, em 35\%. Para alimentar essa população, a produção agrícola terá que duplicar (FAO, ONU, 2016). Pelo quinto ano consecutivo, o crescimento da produtividade agrícola global não está acelerando o suficiente para atender de maneira sustentável às necessidades de alimentos, raçóes, fibras e biocombustíveis de quase 10 bilhóes de pessoas em 2050 (GHI, 2018).

Diante desse cenário, a introdução da biotecnologia na produção de alimentos tornou-se ferramenta utilizada em larga escala a fim de propiciar um cultivo estável e mais produtivo. Conforme aponta Maria Helena Diniz (2009), a tecnologia empregada pode "diminuir problemas advindos da demanda populacional, da nitrificação do solo, da pouca absorção do nitrogênio pelas plantas, da contaminaçáo do solo, da pouca resistência das plantas a certas pragas ou da fácil deterioraçâo dos vegetais" (DINIZ, 2009, p. 726). Conforme definem Naves e Silva os OGMs são "organismos vivos cujo material genético foi alterado por técnicas de engenharia genética, redefinindo suas qualidades" (NAVES; SILVA, 2014, p. 357).

Contudo, apesar dos benefícios da aplicação da técnica, que refletem na redução dos gastos de produção ante a diminuição das despesas com agrotóxico, mão de obra especializada e o tempo gasto no processo de produçáo alimentar, náo se tem certeza quanto a possíveis riscos futuros e desconhecidos. Dessa maneira, "o biodireito vem como uma resposta às indagaçôes que surgem diante das perplexidades e impactos sociais causados pelas inovaçóes científicas." (DINIZ, 2009, p. 01).

É necessário observar que a normatização constitucional de valores de ordem ambiental ${ }^{6}$ faz do Estado de Direito objeto de tomada de uma feição particularizada de paradigma estatal. O Estado Ambiental de Direito supera o modelo liberal, já que a matéria ambiental assume um papel central e é protegida proativamente pelo poder público e sociedade, e o modelo social, visto que a dignidade da pessoa humana agrega uma dimensão ecológica. Dessa maneira, a natureza não é tratada apenas como matéria de exploraçáo com valor econômico, mas se torna uma extensão do próprio indivíduo.

6 Esses valores de ordem ambiental tiverem gênese a partir da Conferência de Estocolmo de 1972 que propôs o equilíbrio entre o desenvolvimento econômico e a reduçấo de seus impactos. Como resultado a "Declaração sobre Meio Ambiente Humano” firmou vinte e seis princípios norteadores para que cada Estado-Naçāo compusesse seu ordenamento jurídico de modo a dar proteção ao reconhecido direito humano a um meio ambiente de qualidade. Na realidade brasileira, como meio de adequaçáo ao compromisso internacional foi promulgada a Lei que dispóe sobre a Política Nacional do Meio Ambiente. Após, a constituição de 1988, que, nas palavras de Paulo Affonso Leme Machado(2013, p. 153), tem como característica a "A universalização dos direitos individuais, sociais e difusos" que constitucionalizou o Direito a um meio ambiente ecologicamente equilibrado com status de Direito Fundamental. 
Assume-se como um dos principais desafios para um meio ambiente ecologicamente equilibrado, direito-dever de todos, a construção de um desenvolvimento sustentável, que consiga balancear os aspectos econômicos e sociais não só visando à perspectiva atual, mas de modo a garantir uma solidariedade intergeracional na proteção do bem ambiental, o que requer uma proteção sistêmica. Conforme aponta Antunes (2017, p. 43): “[...] O Direito Ambiental não pode, sequer, ser imaginado sem uma consideração profunda de seus aspectos econômicos, pois entre seus fins últimos se encontra a regulação da apropriação econômica dos bens naturais".

Observa-se que o tratamento da proteção ambiental é princípio explícito da ordem econômica (art. 170, VI da CF). Logo, busca-se harmonizar e frear os objetivos capitalistas ante a finitude dos bens ambientais. Assim, a construção da proteção ambiental tem como ferramentas princípios norteadores que proporcionam caminhos frente às investidas nocivas ao bem ambiental.

Atenta-se ao princípio da precaução que dita a necessidade de uma posição in dubio pro natura ${ }^{7}$ diante dos riscos advindos de uma incerteza ou imprevisibilidade científica, antes mesmo da exatidão dos resultados. Desse modo, a proteção ambiental náo deve ocorrer somente quando da existência do dano, mas deve ser efetiva para que se antecipe aos riscos e possibilite a interposição das medidas mais eficientes diante a um caso de desastre ambiental. Assevera Machado (2013, p. 99):

A implementação do princípio da precaução não tem por finalidade imobilizar as atividades humanas. Não se trata da precaução que tudo impede ou que em tudo vê catástrofes ou males. $\mathrm{O}$ princípio da precaução visa à durabilidade da sadia qualidade de vida das geraçốes humanas e à continuidade da natureza existente no planeta.

Ao julgar agravo regimental em um recurso especial, a $1^{\text {a }}$ Turma do STJ ${ }^{8}$ valeu-se do princípio da precaução para afastar a instalação de rádio-base, por uma

7 Conforme assevera Machado (2013, p. 111) "Na dúvida, opta-se pela soluçấo que proteja imediatamente o ser humano e conserve o meio ambiente (in dubio pro salute ou in dubio pro natura)".

8 PROCESSO CIVIL E ADMINISTRATIVO. AGRAVO REGIMENTAL NO RECURSO ESPECIAL. SERVIÇO DE TELEFONIA MÓVEL. INSTALAÇĀO DE ESTAÇŌES RÁDIO-BASE. INCIDÊNCIA DO PRINCÍPIO DA PRECAUÇĀO. FUNDAMENTO AUTÔNOMO NĀO IMPUGNADO. SÚMULA 283 DO STF. AUSÊNCIA DE CERTEZA CIENTÍFICA QUANTO AOS EFEITOS QUE A INSTALAÇĀO DE ESTAÇĀO RÁDIO-BASE PRODUZ À SAÚDE HUMANA. PREVALÊNCIA DA DEFESA DO MEIO AMBIENTE.SÚMULA 83/STJ. AGRAVO REGIMENTAL DESPROVIDO. 1. O fundamento autônomo e suficiente à manutenção do decisum objurgado, segundo o qual o caso não comporta juízo de certeza, devendo ser aplicado o princípio da precaução, năo foi alvo de impugnação nas razóes de Recurso Especial, permanecendo, portanto, incólume. Dessa forma, aplicável, na espécie, por analogia, a Súmula 283 do STF. 2. Tendo em vista a ausência de certeza científica quanto aos efeitos que a instalação de estação rádio-base pode causar à saúde humana, prevalece a defesa do meio ambiente em atendimento ao princípio da precauçấo. Precedentes: REsp. 1.285.463/SP, Rel. Min. HUMBERTO MARTINS, DJe 6.3.2012; AgRg na SLS 1.323/CE, Rel. Min. ARI PARGENDLER, DJe 2.8.2011 (AgRg no REsp 1139791/SE, Rel. Ministro NAPOLEĀO NUNES MAIA FILHO, PRIMEIRA TURMA, julgado em 18/10/2016, DJe 26/10/2016)". 
empresa de telefonia que alegava, em síntese, que a atividade não pertencia ao rol de atividades potencialmente poluidoras?

Ademais, a Súmula 618 do STJ ${ }^{10}$ consagra o entendimento de que deve ser aplicada a inversão do ônus da prova em matéria de degradação ambiental. O fundamento para essa posição é a efetividade do princípio da precaução, visto que a responsabilidade de provar a inexistência de riscos da atividade ou do produto, deve recair a quem seja o provável poluidor.

Haja vista a insegurança de que a atividade desempenhada possa acarretar algum risco ao meio ambiente, retorna-se à noção de que, em caso de dúvida, deve-se adotar sempre uma postura que beneficie ao meio ambiente (in dubio pro natura). Portanto, como salienta o Tribunal "uma técnica que sujeita aquele que supostamente gerou o dano ambiental a comprovar que não o causou ou que a substância lançada ao meio ambiente não lhe é potencialmente lesiva” (STJ, 2009).

Frisa-se que as definições de prevenção e precaução apesar de terem como finalidade similar a proteção e preservação do meio ambiente, possuem diferenças. O princípio da precaução abarca a antecipação de riscos hipotéticos, que não possuem certeza científica e que demandam adoção de medidas eficazes para antecipação desses riscos. Já no princípio da prevenção, trata-se de riscos não potenciais, mas constatados. A distinção básica entre os princípios é a que um corresponde a um perigo concreto (no caso da prevenção) e de um perigo abstrato (no caso da precaução) (GUERRA; GUERRA, 2009, p. 136).

Em contraponto, o autor Celso Antônio Pacheco Fiorillo (2013) dispóe que o princípio da precaução "estaria evidentemente colocado dentro do princípio constitucional da prevençáo.” (FIORILLO, p. 71). Salienta que:

[...] ainda que possível argumentar no plano infraconstitucional a existência de um chamado "princípio" da precaução, não deve ele ter base apenas em possibilidade teórica de risco de degradação ambiental; deve prevenir e evitar situação que se mostra efetivamente apta à causação desse dano (FIORILLO, 2013, p. 71).

Não obstante a divergência quanto à natureza do princípio, fato é que a introdução dos OGMs pode, caso não ocorra de maneira cautelosa, atingir proporçōes que superam seus benefícios ${ }^{11}$. Válido destacar o posicionamento de Edis Milaré (2009), em que o princípio "enfrenta a incerteza dos saberes científicos"

9 A Instrução Normativa n. 6 de 15 de março de 2013 regulamenta o Cadastro Técnico de Federal de Atividades potencialmente poluidoras. Em seu anexo I traz um rol exemplificativo de atividades potencialmente poluidoras e extratoras de recursos naturais.

10 A inversão do ônus da prova aplica-se às açōes de degradação ambiental (Súmula 618, CORTE ESPECIAL, julgado em 24/10/2018, DJe 30/10/2018).

11 Os autores Naves e Silva relacionam os principais efeitos negativos da introdução dos OGMs como: [...] a redução ou perda da biodiversidade e a contaminação dos recursos naturais, principalmente a água e o solo. A propagação de certos efeitos toxicológicos no meio ambiente pode ocorrer em cadeia, em virtude da natureza da relação que os organismos estabelecem entre si e com o próprio ecossistema (NAVES; SILVA, 2014, p. 361). 
(MILARÉ, p. 824). Assim, compreende-se como acertado o entendimento de Naves e Silva de que por meio da "delimitação, afastamento e mitigação de riscos incertos sob o ponto de vista científico [o princípio torna-se] um instrumento de garantia dos interesses das geraçôes futuras" (2014, p. 355).

\section{$2 \mathrm{O}$ direito de informaçáo do consumidor e a rotulagem dos alimentos transgênicos}

O consumo, como exercido hodiernamente, teve início com as transformaçôes da revolução industrial, que promoveu a massificação da produção. Dessa maneira, a sociedade dividiu-se entre fabricantes e consumidores. O desequilíbrio inerente dessa relação tornou necessária a adoção de medidas específicas para tutelar o sujeito mais vulnerável, o consumidor.

Essa necessidade de proteção teve reconhecimento internacional, a Resolução n. 39/248 da Organização das Naçôes Unidas (ONU) estabeleceu objetivos e diretrizes acerca da política de proteçáo do consumidor, que serviu como norte para a criação das legislaçôes consumeristas em cada Estado. Na conjuntura brasileira, adotou-se a terminologia Direito do Consumidor, que tem por finalidade a proteção do consumidor ao buscar o equilíbrio da relação, por meio da redução das desigualdades existentes entre consumidor e fabricante.

A defesa do consumidor é um direito fundamental previsto no Art. 50, XXXII, da Constituição Federal de $1988^{12}$. Por conseguinte, é uma cláusula pétrea, com eficácia horizontal, princípio da ordem econômica ${ }^{13}$, regulamentada pela Lei n. 8.078/1990, que institui o Código de Defesa do Consumidor, pautado em princípios, com força normativa, instituído pela Política Nacional de Relaçóes de Consumo.

Entre eles, destaca-se o princípio da vulnerabilidade ${ }^{14}$ que opera como norteador da relação consumerista, haja vista que infere presunção absoluta na vulnerabilidade do consumidor. Conforme aponta o doutrinador Flávio Tartuce (2018) há até mesmo um pleonasmo na definição "consumidor vulnerável", visto que "todos os consumidores têm tal condição, decorrente de uma presunção que não admite discussão ou prova em contrário" (TARTUCE, 2018, p. 49).

Oportuno ressaltar como o CDC estrutura a relação jurídica de consumo. $\mathrm{O}$ código define consumidor como "toda pessoa física ou jurídica que adquire ou utiliza produto ou serviço como destinatário final" (art. $2^{\circ}$ ) e lhe equipara à "coletividade de pessoas, ainda que indetermináveis, que haja intervindo nas relaçôes de consumo" (parágrafo único).

12 Art. 50 Todos săo iguais perante a lei, sem distinção de qualquer natureza, garantindo-se aos brasileiros e aos estrangeiros residentes no país a inviolabilidade do direito à vida, à liberdade, à igualdade, à segurança e à propriedade, nos termos seguintes: [...] XXXII - o Estado promoverá, na forma da lei, a defesa do consumidor;

13 Art. 170. A ordem econômica, fundada na valorização do trabalho humano e na livre iniciativa, tem por fim assegurar a todos existência digna, conforme os ditames da justiça social, observados os seguintes princípios: V defesa do consumidor;

14 Expresso pelo art. $4^{\circ}$, I, do CDC. 
Ao tratar do fabricante, adotou-se um sentido amplo, abarcando o prestador de serviço, o qual consiste em "toda pessoa física ou jurídica, pública ou privada, nacional ou estrangeira, bem como os entes despersonalizados, que desenvolvem atividade de produção, montagem, criação, construção, transformação, importação, exportação, distribuição ou comercialização de produtos ou prestação de serviço" (art. $3^{\circ}$ ). Diante da complexidade da cadeia produtora e de fabricante dos alimentos, restringe-se esta análise à rotulagem, no presente trabalho, e àqueles que os fabricam e sáo responsáveis por seu armazenamento (embalagem) para oferecimento ao público.

Isto posto, o CDC destinou aos consumidores direitos básicos que estão positivados em seu art. $6^{015}$. Ressalta-se que esse rol é exemplificativo e, em função da cláusula de abertura do microssistema do código, esses direitos "não excluem outros decorrentes de tratados ou convençóes internacionais de que o Brasil seja signatário, da legislação interna ordinária, de regulamentos expedidos pelas autoridades administrativas competentes, bem como dos que derivem dos princípios gerais do direito, analogia, costumes e equidade" (Art. 7º, CDC).

Ressalta-se o direito à informação, que também possui previsão constitucional (art. 5, XIV, da CF/88). Esse direito impóe ao fabricante o ônus de que os produtos e serviços contenham "especificação correta de quantidade, características, composição, qualidade, tributos incidentes e preço, bem como sobre os riscos que apresentem” (Art. 6º, III, CDC). Conforme aponta Tartuce (2018), há uma duplicidade no princípio que consiste no "dever de informar e o direito de ser informado, sendo o primeiro relacionado com quem oferece o seu produto ou serviço ao mercado, e o segundo, com o consumidor vulnerável" (TARTUCE, 2018, p. 55). Além disso, acerca das informaçôes prestadas ao consumidor, dispóe o CDC:

Art. 31. A oferta e apresentação de produtos ou serviços devem assegurar informaçôes corretas, claras, precisas, ostensivas e em língua portuguesa sobre suas características, qualidades, quantidade, composição, preço, garantia, prazos de validade

15 Art. 6o São direitos básicos do consumidor:

I - a proteção da vida, saúde e segurança contra os riscos provocados por práticas no fornecimento de produtos e serviços considerados perigosos ou nocivos; II - a educação e divulgaçấo sobre o consumo adequado dos produtos e serviços, asseguradas a liberdade de escolha e a igualdade nas contrataçóes; III - a informaçấo adequada e clara sobre os diferentes produtos e serviços, com especificação correta de quantidade, características, composição, qualidade, tributos incidentes e preço, bem como sobre os riscos que apresentem; IV - a proteçấo contra a publicidade enganosa e abusiva, métodos comerciais coercitivos ou desleais, bem como contra práticas e cláusulas abusivas ou impostas no fornecimento de produtos e serviços; $\mathrm{V}$ - a modificação das cláusulas contratuais que estabeleçam prestaçóes desproporcionais ou sua revisão em razāo de fatos supervenientes que as tornem excessivamente onerosas; VI - a efetiva prevençáo e reparação de danos patrimoniais e morais, individuais, coletivos e difusos; VII - o acesso aos órgãos judiciários e administrativos com vistas à prevençăo ou reparaçấo de danos patrimoniais e morais, individuais, coletivos ou difusos, assegurada a proteçấo Jurídica, administrativa e técnica aos necessitados; VIII - a facilitação da defesa de seus direitos, inclusive com a inversão do ônus da prova, a seu favor, no processo civil, quando, a critério do juiz, for verossímil a alegação ou quando for ele hipossuficiente, segundo as regras ordinárias de experiências; IX(Vetado); X-a adequada e eficaz prestação dos serviços públicos em geral. Parágrafo único. A informação de que trata o inc. III do caput desse artigo deve ser acessível à pessoa com deficiência, observado o disposto em regulamento. 
e origem, entre outros dados, bem como sobre os riscos que apresentam à saúde e segurança dos consumidores.

No que tange aos alimentos transgênicos, a Lei de Biossegurança em seu art. $40^{\circ}$ define a obrigatoriedade da informação da origem de sua composiçáo, conforme regulamento, na rotulagem dos alimentos e ingredientes alimentares destinados ao consumo humano ou animal que contenham ou sejam produzidos a partir de OGMs ou derivados.

O regulamento a que se refere a lei supra é realizado pelo decreto 4.680/03, este prevê que, "na comercialização de alimentos e ingredientes alimentares destinados ao consumo humano ou animal que contenham ou sejam produzidos a partir de organismos geneticamente modificados, com presença acima do limite de um por cento do produto, o consumidor deverá ser informado da natureza transgênica desse produto" (Art. 2º, DL 4680/03). Além disso, dispóe o decreto, no $\$ 1^{\circ}$ do art. $2^{\circ}$ :

$\$ 1^{\circ}$ Tanto nos produtos embalados como nos vendidos a granel ou in natura, o rótulo da embalagem ou do recipiente em que estão contidos deverá constar, em destaque, no painel principal e em conjunto com o símbolo a ser definido mediante ato do Ministério da Justiça, uma das seguintes expressôes, dependendo do caso: "(nome do produto) transgênico", "contém (nome do ingrediente ou ingredientes) transgênico(s)" ou "produto produzido a partir de (nome do produto) transgênico".

Esse símbolo foi definido pela portaria n. 2.658 de 22 de dezembro de 2003 e consiste em um triângulo amarelo que contém em seu centro um "T" maiúsculo em preto.

\subsection{O projeto de lei $n .4 .148 / 2008$}

O Projeto de Lei n. 4.148/2008, em tramitação no Senado Federal como PLC n. $34 / 2015^{16}$, propõe a alteração da Lei de Biossegurança (Lei n. 11.105/2005) e, portanto, altera a rotulagem de alimentos transgênicos no Brasil, pela revogaçáo tácita da portaria do Ministério da Justiça n. 2.658/2003. Suas principais alteraçôes consistem em:

16 O Projeto de Lei 4148/08 é de autoria de Luiz Carlos Heinze à época deputado federal pelo PP-RS. A matéria foi aprovada em 28/08/15 com 320 votos a 135, na forma de uma emenda. Remetido ao Senado Federal a proposta já foi examinada em cinco colegiados e recebeu parecer pela rejeição nas comissóes de Ciência, Tecnologia, Inovação, Comunicação e Informática (CCT), Assuntos Sociais (CAS) e Comissão de Transparência, Governança, Fiscalização e Controle e Defesa do Consumidor (CTFC). Já as comissôes de Agricultura e Reforma Agrária (CRA) e de Meio Ambiente (CMA) aprovaram a retirada do selo. Até o fechamento do presente artigo, em consulta ao site do Senado Federal aos 07 de junho de 2020, a proposta encontra-se em aguardo para apreciação da Comissão de Assuntos Econômicos (CAE). 
Rotular como transgênicos apenas os alimentos cuja presença de OGM for comprovadamente detectada através de "análise específica";

Facultar a rotulagem "livre de transgênicos" aos alimentos para os quais a referida "análise específica" tenha resultado negativo sobre a presença de OGMs; e Retirar o símbolo "T", atualmente utilizado para a identificaçăo de alimentos transgênicos, substituindo-o pelas expressốes "(nome do produto) transgênico" ou "contém (nome do ingrediente) transgênico".

Como justificativa para a alteração legislativa, alega-se que o símbolo, o triângulo amarelo com a letra "T" em maiúsculo, é interpretado pelo consumidor como um sinal de perigo, em decorrência disso a figura serviria como uma contrapropaganda do produto, que conduz ao erro, classificando-o como um conteúdo inútil, visto que não cumpriria seu papel de esclarecimento.

Ademais, propóe-se o critério da detectabilidade em contraponto ao critério atualmente usado, o da rastreabilidade. Alega-se, em síntese, que tal critério é frágil e que sua comprovação ocorre por meio de certificados. Assim, o método causa prejuízos ao comércio nacional, haja vista os custos para a certificação, que prejudica os produtores nacionais. Aduz, ainda, que os produtos importados não passam por esse critério em sua fiscalização, isto acaba por exercer influência no preço final, tornando-os mais atrativos para o mercado em detrimento dos produtos nacionais.

As controvérsias quanto à matéria do projeto de lei impactam a decisão quanto a sua aprovaçáo, sendo que as comissóes que se manifestaram no trâmite legislativo adotaram posturas díspares.

Por meio de Nota Técnica Jurídica elaborada em parceria, o Instituto Socioambiental (ISA), Instituto Brasileiro de Defesa do Consumidor (IDEC) e a Organizaçáo Terra de Direitos e Movimento dos Pequenos Agricultores (MPA), também se manifestaram contrários ao projeto de lei, em razão da afronta aos direitos dos consumidores. Destacando a inadequação da substituiçáo do símbolo "T", haja vista que:

[...] o símbolo "T" já se encontra devidamente sedimentado no inconsciente da população, sendo forma simples, clara e didática de informar ao consumidor sobre a presença de transgênicos. Aliás, interessante notar que, segundo a lógica estabelecida no inconsciente popular pela sua adoção, a ausência deste símbolo nos produtos pode induzir o consumidor a pressupor pela inexistência de transgênicos. 
Além de ressaltar a possibilidade de impactos negativos econômicos e diplomáticos para o país:

Certamente, seja em razão da relevância da correção e adequação da informação para o mercado internacional, seja em decorrência da proibição ou das restriçōes a produtos transgênicos em alguns países (como o exemplo da França, [...]), seja ainda pelas severas limitações impostas ao uso de alguns dos agrotóxicos largamente utilizados no Brasil, os mencionados resultados práticos advindos da eventual aprovaçấo do PL n. 4.148/2008 jamais seriam aceitos internacionalmente, o que causaria severos impactos negativos à economia nacional, notadamente à exportação do setor agropecuário.

Outrossim, a proposta legislativa tem enorme rejeição. De acordo com a pesquisa pública realizada no endereço virtual do Senado, em consulta realizada em 18 de julho de 2020, infere-se que de 24.591 votos, somente 1.111 deles são a favor da proposição legislativa.

Diante das possíveis alteraçóes da proposta legislativa que podem atingir pontos sensíveis da exportação de alimentos é oportuno ressaltar como a questão é tratada por outros países. Conforme apontam Pozzetti e Fontes (2014), o tipo de controle de aprovação dos transgênicos "reflete a escolha entre abrir mercados e investir em biotecnologia ou adotar severos mecanismos de proteção aos consumidores" (POZZETTI; FONTES, p. 43).

A União Europeia, por meio do regulamento n. $1830 / 2003^{17}$, dispóe sobre a rastreabilidade e rotulagem de OGMs, bem como para produtos alimentícios para o consumo animal. Exige-se que os Estados-membros garantam a rastreabilidade e rotulagem do produto em todas as fases de sua colocação no mercado ${ }^{18}$. Além disso, o limite de percentual de material geneticamente modificado aceito para a não informação do bloco é mais rigoroso, visto que acima do percentual de $0,9^{19}$ torna-se necessária a rotulagem, o que vai de encontro com o percentual de 1, $0 \%$ sugerido pela proposta legislativa.

Por sua vez, a rotulagem de produtos derivados de OGMs nos Estados Unidos não é obrigatória, visto que o órgão Food and Drug Administration (FDA) determinou que estes são substancialmente semelhantes a seus equivalentes que não contam com a técnica da transgenia. É válido frisar que a estratégia da

17 Relativo à rastreabilidade e rotulagem de organismos geneticamente modificados e à rastreabilidade dos gêneros alimentícios e alimentos para animais produzidos a partir de organismos geneticamente modificados e que altera a Directiva 2001/18/CE.

18 A Directiva 2001/18/CE do Parlamento Europeu e do Conselho, de 12 de Março de 2001, relativa à libertaçāo deliberada no ambiente de organismos geneticamente modificados, exige que os Estados-membros adotem medidas para garantir a rastreabilidade e rotulagem dos OGMs autorizados, em todas as fases de sua colocaçáo no mercado. 19 Art. 7o 2 :"No que respeita aos produtos destinados ao processamento directo, o disposto no no 1 não é aplicável aos vestígios de OGMs autorizados numa proporção não superior a $0,9 \%$ ou a limiares mais baixos estabelecidos ao abrigo do n. 2 do art. $30^{\circ}$, desde que a presença desses vestígios seja acidental ou tecnicamente inevitável.” 
equivalência substancial é questionada, por dispensar a falta de critérios rigorosos ${ }^{20}$.

Nota-se o contraste de tratamento da matéria no âmbito internacional. Contudo, em observância ao ordenamento pátrio percebe que o projeto de lei propóe alteraçóes que cerceiam o efetivo direito de informação do consumidor. Suas justificaçóes visam um benefício aos fabricantes de alimentos e das indústrias detentoras da tecnologia para criação dos transgênicos, o que agrava ainda mais a vulnerabilidade do consumidor. Resultado totalmente contrário à ordem estabelecida constitucionalmente, sendo necessária uma reflexão acerca da responsabilidade do fabricante do produto alimentício.

Frisa-se que, a despeito de todas as incógnitas quanto à segurança dos alimentos transgênicos, o direito fundamental do consumidor à informação não é decorrente da possibilidade desses riscos, mas do dever do fornecedor de prestar as informaçóes adequadas. Estas são extremamente necessárias para a autonomia dos consumidores como sujeitos ativos do mercado. Ademais, o consumo consciente somente se efetiva com consumidores que tenham a sua disposição e de fácil modo de interpretação, tais informaçôes.

A rotulagem e a identificação dos transgênicos é forma de cumprimento do Código de Defesa do Consumidor e de prevalência da vontade do cidadão, que, assim, pode decidir o consumo baseado em informaçóes seguras e precisas. Em razão disso, políticas públicas de biossegurança e segurança alimentar devem ser pautadas em fornecer informação integral e de qualidade aos consumidores.

\section{A responsabilidade civil do fabricante de alimentos geneticamente modificados}

O instituto da responsabilidade civil encontra previsão no art. 927 do Código Civil que dispóe "Art. 927. Aquele que, por ato ilícito (arts. 186 e 187), causar dano a outrem, fica obrigado a repará-lo." (BRASIL, 2002). No mesmo sentido, a Lei define o conceito de ato ilícito, nos arts. 186 e 187.

Art. 186. Aquele que, por ação ou omissão voluntária, negligência ou imprudência, violar direito e causar dano a outrem, ainda que exclusivamente moral, comete ato ilícito. Art. 187. Também comete ato ilícito o titular de um direito que, ao exercê-lo, excede manifestamente os limites impostos pelo seu fim econômico ou social, pela boa-fé ou pelos bons costumes (BRASIL, 2002).

Nesse sentido, cabe destacar as duas classificaçóes da responsabilidade civil. Verifica-se que o art. 186 trata do que chamamos de responsabilidade subjetiva,

20 "As plantas transgênicas, aprovadas para o cultivo comercial nos Estados Unidos, tiveram sua liberação baseada no princípio da equivalência substancial. Assim, a soja RR foi considerada "equivalente" a sua antecedente natural, a soja convencional, porque não difere dela nos aspectos cor, textura, teor de óleo, composiçáo e teor de aminoácidos essenciais e de nenhuma outra qualidade bioquímica." (NODARI; GUERRA. 2001.p. 91). 
ou seja, aquela responsabilidade que depende da comprovação do elemento culpa para se concretizar.

Já o art. 927 trata da responsabilidade objetiva, ou seja, aquela em que basta a comprovaçáo do ato ilícito e do resultado danoso para que surja o dever de indenizar, não havendo que se falar em culpabilidade. No parágrafo único do artigo supracitado, destaca-se a disposição da obrigação de reparar o dano objetivamente, nos casos em que a atividade desenvolvida pelo autor implicar, em virtude de sua natureza, risco para os direitos de outrem. Assim, o parágrafo único do art. 927 do Código Civil traz à baila a teoria da responsabilidade civil objetiva baseada no risco. Acerca da teoria do risco, Nelson Rosenvald assevera:

a teoria objetiva, qualquer pessoa pode deliberar pela realização de uma atividade econômica. Empreender é próprio da sociedade capitalista e do instinto humano. O termo risco é oriundo do italiano "risicare", que significa "ousar" ou "aventurar". Pois bem, aquele que delibera por assumir o risco inerente a uma atividade deverá se responsabilizar por todos os danos dela decorrentes, independentemente da existência de culpa. Se a opção do agente é de ousar e se aventurar, necessariamente arcará com os custos relacionados à trasladaçáo dos danos sofridos pela vítima, sem se considerar a licitude ou ilicitude da conduta. A partir do momento em que a teoria objetiva liberta o acesso à reparação de danos do filtro da culpa, delibera por aceitar a ideia de que mesmo se o caso concreto não demonstrar a prática do comportamento antijurídico, em certas circunstâncias será socialmente mais justo atribuir o pagamento da indenizaçấo àquele que administra o risco da atividade (ROSENVALD, 2017, p. 513).

A sociedade em que vivemos, fruto de um processo de industrialização e consumo exacerbados, produziu grandes avanços, mas em consequência, produziu vários efeitos negativos, alguns já conhecidos, como as mudanças climáticas, os desastres ambientais, catástrofes derivadas da manipulação nuclear, e outros efeitos ainda desconhecidos, derivados do aumento de tecnologia e desenvolvimento. Aos efeitos desconhecidos, atribuímos o valor risco, uma vez que na sociedade em que vivemos, são intrínsecos ao desenvolvimento. Acerca da sociedade de risco, Ulrich Beck assevera:

[...] o que significa que a dinâmica da sociedade de risco se baseia menos na suposição de que temos de viver, hoje e no futuro, num mundo de perigos inéditos e mais na ideia de que vivemos num mundo que tem de decidir o seu futuro nas condiçôes de 
insegurança produzida, fabricada por si próprio. Isto implica que o mundo deixou de poder controlar os perigos gerados pela modernidade, ou melhor, que a crença segundo a qual a sociedade moderna poderia controlar os perigos por ela criados está a desmoronar-se - não devido a falhas e a derrotas da modernidade, mas sim às suas vitórias (BECK, 2015, p. 20).

Cabe ressaltar que a existência de riscos é inerente ao desenvolvimento da sociedade atual, todavia, deve-se observar o princípio da precaução, conforme tratado anteriormente no presente trabalho, uma vez que náo se trata de impedir o desenvolvimento caso ele esteja cercado de incerteza, e sim de garantir, ou tomar as medidas de segurança e cerificação necessárias para que o risco seja minimizado ou extinto. Nesse sentido, Silva assevera:

Diante da certeza do risco, isto é, diante de riscos demonstrados (risques avérés), o princípio da prevenção preconiza que medidas sejam adotadas para evitar o dano. $\mathrm{Na}$ área de biossegurança, quando os riscos não dependem do querer humano, ou seja, quando não é possível evitar o dano, o princípio da prevenção preconiza a adoçấo de medidas de proteçâo, visando à redução das consequências danosas. Tanto num quanto n'outro caso, o modelo de decisão é fundado na segurança. Considerando as hipóteses em que impera a incerteza e as informaçôes existentes não são conclusivas, isto é, em face de riscos hipotéticos (risques hypothétiques), o princípio da precaução preconiza a adoção de medidas tendentes a não gerar o dano (SILVA, 2007, p. 302).

No caso em comento, o risco é determinante para a responsabilização, uma vez que ao assumir o risco da atividade e obter vantagens ligadas diretamente à natureza arriscada dos organismos geneticamente modificados, o indivíduo também se expóe a maior probabilidade de que aquela atividade venha a causar dano a outrem, e por essa relaçáo entre risco e proveito assume objetivamente a responsabilidade. Nesse sentido, Sergio Cavelieri Filho assevera:

Em suma, quem se dispóe a exercer alguma atividade perigosa terá que fazê-lo com segurança, de modo a não causar dano a ninguém, sob pena de ter que por ele responder independentemente de culpa. Aí está, em nosso entender, a síntese da responsabilidade objetiva. Se, de um lado, a ordem jurídica garante a liberdade de açâo, a livre iniciativa etc., de outro, garante também a plena e absoluta proteção do ser humano. Há um direito subjetivo à segurança cuja violação justifica a obrigação de reparar o dano 
sem nenhum exame psíquico ou mental da conduta do seu autor. $\mathrm{Na}$ responsabilidade objetiva, portanto, a obrigação de indenizar parte da ideia de violação do direito de segurança da vítima (CAVALIERI FILHO, 2012, p. 155-156).

Quando tratamos da responsabilidade civil dos fabricantes de alimentos geneticamente modificados, o elemento risco está presente em toda a cadeia produtiva, visto que, apesar do aumento de produção, e a facilidade de manejo, os efeitos desses alimentos no organismo humano ainda são desconhecidos. Então, ao optar por comercializar o alimento modificado, o fabricante assume o risco do desconhecimento de resultado.

Além disso, por se tratar de uma relação de consumo, há que se falar na incidência do Código de Defesa do Consumidor que por sua vez dispóe acerca da responsabilidade do fabricante.

Art. 12. O fabricante, o produtor, o construtor, nacional ou estrangeiro, e o importador respondem, independentemente da existência de culpa, pela reparaçấo dos danos causados aos consumidores por defeitos decorrentes de projeto, fabricação, construção, montagem, fórmulas, manipulação, apresentaçấo ou acondicionamento de seus produtos, bem como por informaçóes insuficientes ou inadequadas sobre sua utilização e riscos (BRASIL, 1990).

$\mathrm{Na}$ relação consumerista a responsabilidade civil do fabricante independe de culpa, ou seja, trata-se de responsabilidade objetiva. Nesse sentido, Gonçalves assevera:

O consumidor, em razão da solidariedade passiva, tem direito de endereçar a reclamaçáo ao fornecedor imediato do bem ou serviço, quer se trate de fabricante, produtor, importador, comerciante ou prestador de serviços, como também pode, querendo, acionar o comerciante e o fabricante do produto, em litisconsórcio passivo (GONÇALVES, 2011. p. 282).

Nesse sentido, a responsabilidade não é atraída apenas pelo fabricante do alimento geneticamente modificado, mas também pelo proprietário da patente do OGM, pelo produtor que cultiva a semente, pela transportadora, bem como pela indústria processadora do alimento, e a distribuidora, uma vez que assumem o risco ao exercerem sua atividade baseada em um alimento que possui incerteza científica quanto a seus reais efeitos.

O Código de Defesa do Consumidor faz uma ressalva quanto ao comerciante, em seu art. 13, dispondo acerca das hipóteses nas quais será responsabilizado, 
quais sejam: "I - o fabricante, o construtor, o produtor ou o importador não puderem ser identificados; II - o produto for fornecido sem identificação clara de seu fabricante, produtor, construtor ou importador; III - não conservar adequadamente os produtos perecíveis." Assim, o CDC, consagra uma responsabilidade subsidiária para o comerciante em relaçáo aos outros integrantes da cadeia produtiva, tendo em vista a vulnerabilidade do primeiro em face dos demais agentes.

No que tange à objetividade da responsabilização do fabricante não resta dúvida, entretanto, o presente trabalho trata da responsabilização do fabricante diante da ausência de informaçóes no rótulo de alimentos geneticamente modificados, que poderá ser autorizada pelo Projeto de Lei 4.148/2008.

A necessidade do fornecimento de informaçóes claras ao consumidor é elencada no art. $6^{\circ}$, III, do CDC, e dispóe acerca da necessidade das informaçóes referentes à quantidade, características, composição e qualidade, bem como dos tributos incidentes, mas em especial trata da necessidade da informação dos riscos que podem ser apresentados pelo produto (BRASIL, 1990). No mesmo sentido, os arts. $9^{\circ}$ e $10^{\circ}$ do CDC dispóem sobre a obrigatoriedade de que o fabricante informe o consumidor de maneira ostensiva e adequada quanto aos potenciais perigos inerentes a seu produto ou serviço caso existam, além da obrigatoriedade de náo colocar produto no mercado em que saiba haver alto grau de nocividade ou periculosidade à saúde e à segurança (BRASIL, 1990).

O Projeto de Lei n. 4.148/2008 vai de encontro a todas as determinaçóes quanto a obrigatoriedade de informaçôes para o consumidor, conforme explicitado anteriormente neste trabalho, uma vez que defende a disponibilização da informação acerca da existência de transgênico no produto apenas nos casos em que ao final da produçáo ele seja encontrado percentualmente em maior quantidade do que $1 \%$. Além disso propóe a retirada do símbolo "T" das embalagens, bem como a retirada da informaçáo acerca da espécie doadora do gene (BRASIL, 2008).

Nessa perspectiva, é possível afirmar que a responsabilidade do fabricante de alimentos geneticamente modificados quanto a ausência de informação no rótulo dos produtos é objetiva, uma vez que além de estar sob a égide do Código do Consumidor, possui obrigatoriedade legal e constitucional de informar seu consumidor acerca dos potenciais riscos inerentes a seu produto. Ainda que os possíveis danos causados pelo consumo de alimentos geneticamente modificados não estejam provados, o consumidor deve ter o direito de escolher não correr os riscos inerentes a seu consumo.

\section{Consideraçóes finais}

O consumo de alimentos geneticamente modificados é uma realidade em todo o mundo, o crescimento populacional faz que a demanda por alimentos aumente em uma velocidade exponencial, assim como o plantio de OGMs. A 
biotecnologia e a edição genética vieram para somar, para fazer que o ser humano possa ir além, todavia, sua utilização sem os devidos critérios pode trazer prejuízos gravíssimos.

A ausência de estudos efetivos de impacto ambiental foi constatada durante a liberação comercial dos organismos geneticamente modificados no Brasil. O que coloca o consumidor e o cidadão em uma posição de extrema vulnerabilidade, já que consome um produto que não foi efetivamente estudado pelo órgáo que o aprovou. Existe uma grande variedade de alimentos geneticamente modificados no mundo, todavia, a pressão exercida pelas grandes indústrias monopolizadoras desse mercado, fez que o grande mercado mundial se reduzisse a pouquíssimas variedades comercializadas em grande escala.

Seria muito radical taxar os OMGs como vilóes, ou associá-los imediatamente ao risco, mas dadas as circunstâncias eles devem ser tratados com alto grau de incerteza, e deixados os interesses econômicos de lado, e efetivamente estudados, para que cumpram seu propósito.

Acerca do direito à informaçáo, cabe salientar que este é mais profundo do que a simples disposição de informaçôes no rótulo dos produtos. Quando tratamos de alimentos transgênicos, lidamos com um grande desconhecimento por parte da população acerca de seus possíveis riscos. Não há que se falar em informação sem o conhecimento de seus principais riscos, a disposição de características no rótulo de um produto tão específico, não informa, apenas o diferencia. Para que esse direito seja realmente efetivado quanto ao consumo de organismos geneticamente modificados, devemos falar em ampliação da informação, em políticas públicas que vinculem o comércio de produtos OGMs à comerciais informativos, ou a verba destinada a pesquisa dos reais efeitos desses organismos.

Portanto, conclui-se que, por estar sob a égide do Código do Consumidor, bem como das disposiçóes do Código Civil, o fabricante deverá responder objetivamente pela ausência de informaçôes ao consumidor, todavia, temerosa se faz a possibilidade de aprovação do Projeto de Lei tratado no presente trabalho, posto que diante das incertezas inerentes à produção do alimento transgênico, deveríamos estar tratando de um fortalecimento da legislação bem como um aumento de incentivo a pesquisa e estudo de impactos ambientais, e náo da ausência de informaçôes para o consumidor. No caso da aprovação, apenas a responsabilizaçáo objetiva não seria suficiente para a proteçáo do consumidor, uma vez que as indenizaçóes jamais ultrapassaráo o limite do lucro auferido pela ocultação de informaçôes no rótulo dos produtos.

\section{Referências}

ALVES, G. S. A biotecnologia dos transgênicos: precaução é a palavra de ordem. Holos, Natal, v. 2, out. 2004. Disponível em: <http://www2.ifrn.edu.br/ojs/index. php/HOLOS/article/view/33/34>. Acesso em: 15 jun. 2020. 
ANTUNES, P. B. Direito Ambiental. 19. ed. rev. e atual. São Paulo: Atlas, 2017.

ARAGÃO. F. J. L. A trajetória dos organismos transgênicos. Embrapa. Disponível em: <https://www.embrapa.br/olhares-para-2030/artigo/-/asset_publisher/SNN1QE9zUPS2/content/francisco-jose-lima-aragao?inheritRedirect=true>. Acesso em: 15 jun. 2020.

BECK, U. Sociedade de risco mundial - em busca da segurança perdida. Lisboa: Edições 70, 2015. [E-book].

BRASIL. Câmara dos Deputados. Projeto de Lei n. 4148/2008. Altera e acresce dispositivos à Lei n. 11.105, de 24 de março de 2005. Estabelece que os rótulos dos alimentos destinados ao consumo humano informem ao consumidor a natureza transgênica do alimento. Brasília, DF, 2008. Disponível em: https://www. camara.leg.br/proposicoesWeb/fichadetramitacao?idProposicao=412728. Acesso em: 20 mai. 2020.

BRASIL. Constituição (1988). Constituição da República Federativa do Brasil. Brasília: Senado Federal, Centro Gráfico, 1988.

BRASIL. Decreto n. 4.680, de 24 de abril de 2003. Regulamenta o direito à informação, assegurado pela Lei no 8.078, de 11 de setembro de 1990, quanto aos alimentos e ingredientes alimentares destinados ao consumo humano ou animal que contenham ou sejam produzidos a partir de organismos geneticamente modificados, sem prejuízo do cumprimento das demais normas aplicáveis. Publicado no D.O.U. de 24.04.2003, disponível em: <https://www.planalto.gov.br/ccivil_03/ decreto/2003/D4680.htm>. Acesso em: 15 jun. 2020.

BRASIL. Decreto n. 5.705, de 16 de fevereiro de 2006. Promulga o Protocolo de Cartagena sobre Biossegurança da Convenção sobre Diversidade Biológica. Brasília, DF, 2006. Disponível em: <http://www.planalto.gov.br/ccivil_03/_ato20042006/2006/decreto/D5705.htm>. Acesso em: 15 jun. 2020.

BRASIL. Lei n. 8.078, de 11 de setembro de 1990. Dispóe sobre a proteção do consumidor e dá outras providências. Publicado no Diário Oficial da União de 11 de setembro de 1990. Disponível em: <http://www.planalto.gov.br/ccivil_03/leis/ 18078.htm>. Acesso em: 15 jun. 2020.

BRASIL. Lei n. 10.406 de 10 de janeiro de 2002. Institui o Código Civil. Disponível em: <http://www.planalto.gov.br/ccivil_03/leis/2002/110406.htm\#art186>. Acesso em: 5 jun. 2020.

BRASIL. Lei n. 10.688 de 13 de junho de 2003. Estabelece normas para a comercialização da produção de soja da safra de 2003 e dá outras providências. Disponível em: <http://www.planalto.gov.br/ccivil_03/LEIS/2003/L10.688.htm>. Acesso em: 15 jun. 2020. 
BRASIL. Lei n. 11.105, de 24 de março de 2005. Regulamenta os incs. II, IV e $\mathrm{V}$ do $\$ 1^{\circ}$ do art. 225 da Constituiçáo Federal, estabelece normas de segurança e mecanismos de fiscalização de atividades que envolvam organismos geneticamente modificados - OGM e seus derivados, cria o Conselho Nacional de Biossegurança - CNBS, reestrutura a Comissão Técnica Nacional de Biossegurança - CTNBio, dispóe sobre a Política Nacional de Biossegurança - PNB, revoga a Lei n. 8.974, de 5 de janeiro de 1995, e a Medida Provisória n. 2.191-9, de 23 de agosto de 2001 , e os arts. $5^{\circ}, 6^{\circ}, 7^{\circ}, 8^{\circ}, 9^{\circ}, 10^{\circ}$ e $16^{\circ}$ da Lei n. 10.814 , de 15 de dezembro de 2003, e dá outras providências. Brasília, DF, março 2015 Disponível em: <http://www.planalto.gov.br/ccivil_03/_ato2004-2006/2005/lei/l11105.htm>. Acesso em: 15 jun. 2020.

BRASIL. Medida Provisória n. 113, de 26 de março de 2003. Estabelece normas para a comercialização da produção de soja da safra de 2003 e dá outras providências. Disponível em: <http://www.planalto.gov.br/ccivil_03/MPV/Antigas_2003/113.htm>. Acesso em: 15 jun. 2020.

BRASIL. Superior Tribunal de Justiça. 2a Turma. REsp 1060753 SP 2008/01130826, Rel. Ministra Eliana Calmon, DJe 214/12/2009.

BRASIL. Superior Tribunal de Justiça. Súmula n. 618. Disponível em: <https:// scon.stj.jus.br/SCON/sumanot/toc.jsp\#TIT1TEMA0>. Acesso em: 13 jun. 2020.

CAVAliERI FILHO, S. Programa de responsabilidade civil. 10. ed. São Paulo: Atlas, 2012.

DINIZ, M. H. O estado atual do biodireito. 6. ed. São Paulo: Saraiva, 2009.

FAO: Como alimentar a crescente população global? Organização das $\mathrm{Na}$ çóes Unidas (ONU). 16 jun. 2016. Disponível em: < https://nacoesunidas. org/fao-como-alimentar-a-crescente-populacao-global/\#:- :text=Em $\% 20$ 2050\%2C\%20a\%20popula\%C3\%A7\%C3\%A3o\%20mundial,maiores\%20perigos\%20para\%20o\%20mundo.>. Acesso em: 17 ago. 2020.

FIORILlO, C. A. P. Curso de Direito Ambiental Brasileiro. 13. ed. São Paulo: Saraiva, 2012.

FIUZA, C. et al. A responsabilidade civil dos fornecedores de alimentos transgênicos. Meritum, Revista de Direito da Universidade FUMEC, Belo Horizonte, v. 13, n. 2, p. 84-108, jul./dez. 2018. Disponível em: <http://www.fumec.br/revistas/ meritum/article/view/6726>. Acesso em: 15 jun. 2020

GHI - GLOBAL HARVEST INITIATIVE. 2018 Global Agricultural Productivity Report. Washington, D.C.: DHI, 2018. Disponível em: https://globalagricultu- 
ralproductivity.org/wp-content/uploads/2019/01/GHI_2018-GAP-Report_FINAL-10.03.pdf. Acesso em: 28 ago. 2020.

GONÇALVES, C. R. Direito Civil brasileiro: responsabilidade civil. v. 4. São Paulo: Saraiva, 2011.

GUERRA, S.; GUERRA, S. Curso de Direito Ambiental. Belo Horizonte: Fórum, 2009 .

ISAAA - INTERNATIONAL SERVICE FOR THE ACQUISITION OF AGRI-BIOTECH APPLICATIONS. A situação global dos cultivos biotecnológicos/GM comercializados em 2017: a adoção de cultivos biotecnológicos aumenta com os benefícios econômicos acumulados em 22 anos. ISAAA Brief 53. Ithaca: ISAAA, 2017. Disponível em: <https:/www.isaaa.org/resources/publications/ briefs/53/executivesummary/pdf/B53-ExecSum-Portuguese.pdf>. Acesso em: 15 jun. 2020.

ISAAA - INTERNATIONAL SERVICE FOR THE ACQUISITION OF AGRI-BIOTECH APPLICATIONS. Biotech Crops Continue to Help Meet the Challenges of Increased Population and Climate Change. Press Release. Ithaca: ISAAA, 2018. Disponível em: <http://www.isaaa.org/resources/publications/briefs/54/pressrelease/pdf/B54-PressRelease-English.pdf>. Acesso em: 15 jun. 2020.

LEITE, M. Os alimentos transgênicos. São Paulo: Publifolha, 2000.

LOPEZ, T. A. Princípio da precaução e evolução da responsabilidade civil. São Paulo: Quartier Latin, 2010.

MACHADO, P. A. L. Direito Ambiental brasileiro. 21. ed. São Paulo: Malheiros, 2013.

MILARÈ, E. Direito do Ambiente: gestão ambiental em foco. 6. ed. São Paulo: Revista dos Tribunais, 2009.

NAVES, B. T. O.; SILVA, M. V. Organismos geneticamente modificados sob a perspectiva da tutela das geraçóes futuras. Veredas do Direito, Belo Horizonte, v. 11, n. 22, p. 355-380, jul./dez. 2014.

NODARI, R. O.; GUERRA, M. P. Avaliação de riscos ambientais de plantas transgênicas. Cadernos de Ciência e Tecnologia, Brasília, DF, v. 18, n. 1, p. 81-116, 2001.

PELAEZ, V.; ALBERGONI, L. Barreiras técnicas comerciais aos transgênicos no Brasil: a regulação nos estados do sul. Indicadores Econômicos FEE, Porto Alegre, v. 32, n. 3, p. 201-230, 2004.

POZZETTI, V. C.; FONTES, G. R. Rastreabilidade de organismos geneticamente modificados (OGMs): instrumento de proteção ao consumidor e ao meio 
ambiente. Veredas do Direito, Belo Horizonte, v.11, n.21, p.31-52, jan./jun. de 2014. Disponível em: <http://revista.domhelder.edu.br/index.php/veredas/article/download/420/396>. Acesso em: 17 ago. 2020.

RODRIGUES, M. R. J. B. Biodireito: alimentos transgênicos. São Paulo: Lemos e Cruz, 2003.

ROSENVALD, N. As funçôes da responsabilidade civil: a reparação e a pena civil. 3. ed. São Paulo: Saraiva, 2017.

SILVA, J. A. Q. C. Alimentos transgênicos: aspectos ideológicos, ambientais, econômicos, políticos e jurídicos. In: SANTOS, M. C. C. Biodireito: ciência da vida, os novos desafios. Sáo Paulo: Revista dos Tribunais, 2001. p. 326-346.

SILVA, R. P. A. biossegurança e o instituto da responsabilidade civil. Revista do Instituto de Pesquisas e Estudos, Bauru, v. 41, n. 47, p. 297-316, jan./jun. 2007.

STJ - Superior Tribunal de Justiça - RECURSO ESPECIAL: REsp 1060753 SP 2008/0113082-6. PROCESSUAL CIVIL. COMPETÊNCIA PARA JULGAMENTO DE EXECUÇÃO FISCAL DE MULTA POR DANO AMBIENTAL INEXISTÊNCIA DE INTERESSE DA UNIÃO - COMPETÊNCIA DA JUSTIÇA ESTADUAL - PRESTAÇÃO JURISDICIONAL - OMISSÃO - NÃO-OCORRÊNCIA - PERÍCIA - DANO AMBIENTAL - DIREITO DO SUPOSTO POLUIDOR - PRINCÍPIO DA PRECAUÇÃO - INVERSÃO DO ÔNUS DA PROVA. Disponível em: <https://www.jusbrasil.com.br/jurisprudencia/busca?q=Stj+resp+1060.753>. Acesso em: 17 ago. 2020.

TARTUCE, F. Manual de direito do consumidor: direito material e processual. 7. ed. rev., atual. e ampl. Rio de Janeiro: Forense; São Paulo: Método, 2018.

THEODORO JÚNIOR, H. Direitos do Consumidor. 9. ed. Rio de Janeiro: Forense, 2017.

UNIĀO EUROPEIA. Regulamento (CE) n. 1830/2003 do Parlamento Europeu e do Conselho, de 22 de Setembro de 2003, relativo à rastreabilidade e rotulagem de organismos geneticamente modficados e à rastreabilidade dos géneros alimentícios e alimentos para animais produzidos a partir de organismos geneticamente modificados e que altera a Directiva 2001/18/CE. Disponível em: <http://eur-lex. europa.eu/legal-content/PT/TXT/?uri=CELEX: 32003R1830>. Acesso em: 15 jul. 2020. 